\title{
Durability of Reinforced Concrete Beams under Simultaneous Flexural Load in Corrosive Environment
}

\author{
Loukas Karavokyros ${ }^{1}$, George Batis ${ }^{1}$, Nikolaos Katsiotis ${ }^{1}$, Emmanouil Tzanis $^{2}$, \\ Margarita Beazi-Katsioti ${ }^{1}$
}

${ }^{1}$ School of Chemical Engineering, National Technical University of Athens, Zografou, Athens, Greece

${ }^{2}$ Titan Cement Group, Laboratory of Concrete Technology, Kamari, Athens, Greece

Email: *loukas.kara@gmail.com

How to cite this paper: Karavokyros, L., Batis, G., Katsiotis, N., Tzanis, E. and Beazi-Katsioti, M. (2020) Durability of Reinforced Concrete Beams under Simultaneous Flexural Load in Corrosive Environment. Journal of Materials Science and Chemical Engineering, 8, 32-45.

https://doi.org/10.4236/msce.2020.84003

Received: March 25, 2020

Accepted: April 20, 2020

Published: April 23, 2020

Copyright (C) 2020 by author(s) and Scientific Research Publishing Inc. This work is licensed under the Creative Commons Attribution-NonCommercial International License (CC BY-NC 4.0). http://creativecommons.org/licenses/by-nc/4.0/

\begin{abstract}
The deterioration of concrete over time is the result of various mechanical, physical, chemical and biological processes, with the corrosion of reinforcement being the most serious problem of durability of reinforced concrete structures. Over the last 50 years, a tremendous effort has been spent by the international scientific community with laboratory research and experimental field studies in order to increase the resistance of concrete over corrosion. This paper presents an experimental study of the corrosion behaviour of reinforced concrete beams with simultaneous sustained flexural loading. For this purpose, 40 reinforced concrete beams of 5 different compositions were constructed and exposed in simulated harmful environmental conditions in 3 different stress ratios for a total period of 42 months. Their behavior against corrosion was determined via regular measurements of the electrical resistance of concrete (according to ASTM G57) and the corrosion potential of the steel-reinforced bars with the use of copper sulphate (CSE) as reference electrode (according to ASTM C876). A theoretical calculation of the corrosion rate was conducted based on the electrochemical measurements of the beams. The results indicate that the corrosion potential of steel decreased in time and more rapidly after the initiation of the corrosion process; the electrical resistance firstly increased, remained stable for a short period and then decreased with the corrosion development, as expected. An inversely proportional relationship of the water/cement ratio of a composition with its corrosion behaviour as well as an analogous relationship between the cement content of a composition and its corrosion behaviour was observed. Also, the corrosion rate of steel is increased gradually with increasing load.
\end{abstract}




\section{Keywords}

Reinforced Concrete Beams, Steel Corrosion, Corrosion Inhibitor, Electrochemical Measurements

\section{Introduction}

In recent years, there have been intense problems of unsatisfactory results in structural durability, with corrosion of reinforcement being the most important problem in reinforced concrete structures. The chloride-induced steel corrosion in reinforced concrete structures (RCS) in marine environments, is of major concern [1] [2]. In general, the high alkalinity of concrete pore solutions leads to a protective passive film on the steel surface which delays the time of corrosion initiation [3] [4]. However, when the content of chloride ions at the steel-concrete interface reaches the chloride threshold level, steel starts to corrode and corrosion products are generated gradually on the steel surface, ultimately leading to premature cracking and spalling of RCSs. To date, many studies have been performed to investigate the corrosion behavior of steel in simulated concrete pore solutions and RCSs in aggressive environments [5] [6] However, little attention has been given to the influence of external loading on the corrosion behavior of steels in concrete. The most vulnerable area of a marine structure is that of the splash or the tidal zone, which are subject to alternating wetting and drying cycles and are considered in this study (exposure categories XS as per EN 206). In effect, it is a well-known fact that RCSs are usually subjected to various types of external loads (compression, tension and flexure, etc.) during the long-term service life [7] [8]. Amongst them, the flexural load is the most common and important load type. Generally, the flexural load affects the three typical processes in the service life of RCSs in marine environments: the passivation stage of steel, the corrosion initiation stage and the corrosion propagation stage. Feng et al. reported that the passivation ability of steels decreased as the tensile stress increased in simulated concrete pore solutions [9] [10]. Under higher stress, irreversible damages occurred in the passive film. However, if the load magnitude was low enough, the micro-cracks in passive film can be completely recovered after unloading. Despite this interest, few researchers as far as we know, have studied the corrosion resistance of steels exposed to different exposure zones under simultaneous flexural load and chlorides attack [11] [12] [13]. Accordingly, the main purpose of this study is to estimate the effect of the permanent loading and the composition (grading, additives, admixtures) of a concrete structure on its durability against harmful environmental conditions.

\section{Experimental}

\subsection{Specimens Description}

A total of $40 \mathrm{RC}$ composite beams were manufactured with dimensions of 150 
$\mathrm{cm}$ in length, $15 \mathrm{~cm}$ in width and $25 \mathrm{~cm}$ in depth. The samples were produced in a ready-mix concrete plant to simulate as best as possible the actual concrete casting conditions. The formwork was fabricated locally using plywood flats. The internal dimensions of the mould are exactly equal to the specimen dimensions. The internal surface of the formwork was properly oiled for easy removal of the specimen from the formwork. The detailed characteristics and reinforcement configuration of the examined beams are shown in Figure 1. The thickness of concrete cover at both tension and compression sides was $20 \mathrm{~mm}$. As shown in Figure 1, four deformed steel bars with diameter of $12 \mathrm{~mm}$ were used as the longitudinal reinforcement. The stirrup was made of an $8 \mathrm{~mm}$ round rebar and arranged in the shear span zone at a spacing of $150 \mathrm{~mm}(\Phi 8 / 150)$. The test beams had a concrete cover depth of $20 \mathrm{~mm}$ [14].

Casting of 40 beam specimens was carried out in 5 batches. Concrete cube specimens were also cast from each batch of concrete mix to determine the corresponding compressive strength. The moulds were oiled and the steel reinforcement cages (prepared beforehand) were placed securely in their respective positions in the moulds. $20 \mathrm{~mm}$ precast blocks were used to maintain a clear cover. The moulds were filled with concrete in two layers. After the placement of each layer, the concrete was vibrated to ensure proper consolidation. The specimens were demoulded after 24 hours of casting and then covered with wet gunny bags. For the first two weeks after casting the beams were cured using wet gunny bags by applying water frequently. After 28 days from casting the beams and the control specimens were stored to dry in the atmosphere until testing [15].

\subsection{Test Setup}

Five groups comprised of eight beam specimens were arranged and each pair of them was subjected to a different exposure condition for a period of 42 months. In order to simulate natural corrosion, the specimens were subjected to tactical surface spray with a $\mathrm{NaCl}$ solution, plus a control group was used as reference and was only exposed to natural environmental conditions. The experiment was carried out in the area of Athens, Metamorphosi where the average annual temperature is $16.4^{\circ} \mathrm{C}$ and the relative humidity ranged from $45 \%$ to $83 \%$ during the course of a year.

The chloride corrosion tests of the RC beams were conducted under sustained flexural loading. Loading was symmetrically applied to a pair of beams using the
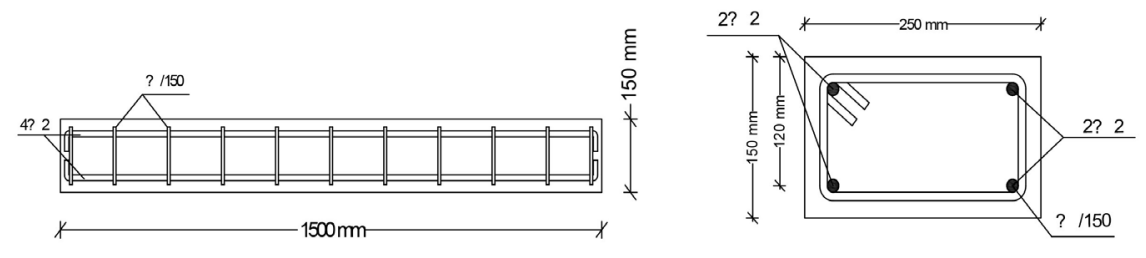

Figure 1. Geometrical characteristics and reinforcement configuration of the examined beams (side view, cross-section view). 
loading set up shown in Figure 2. As shown, the desired loads have been achieved with the use of reinforced concrete blocks ( $850 \mathrm{~kg} / \mathrm{unit}$ ) which were mounted in the middle of the beams. The parameters for the corrosion tests included concrete mix designs, corrosion level, and loading level. The sustained load was calculated as $0 \%, 7 \%$ and $20 \%$ of the yielding point of non-corroded RC beams. The yielding loads obtained were $0 \mathrm{KN} \times \mathrm{m}$ (unloaded), $2 \mathrm{KN} \times \mathrm{m}, 6 \mathrm{KN}$ $\times \mathrm{m}$, respectively.

\subsection{Materials and Properties}

The tested concrete compositions were selected in accordance with the limitations set by the latest concrete technology regulations, for near sea structures, which are: conventional concrete quality $\mathrm{C} 30 / 37$ ( $\mathrm{CC} 1$ reference composition), CC with additional corrosion inhibitor $4 \% \mathrm{w} / \mathrm{w}$ of cement (CC2), CC with surface sprayed sealant (CC3), self-compacting concrete (SCC) and fine aggregate concrete with absence of coarse aggregate, $d_{\max }<16 \mathrm{~mm}$ (FAC).

The concrete mix designs were prepared in a ready-made concrete plant. The mixture proportions ratio for the reference concrete (CC) was as follows: cement: water: sand: fine aggregate: coarse aggregate $=1: 0.50: 3: 3: 2.8$ by weight. For the SCC was cement: water: sand: fine aggregate: coarse aggregate $=1: 0.40: 2.1: 2.1: 1.1$ by weight. For the fine aggregate concrete (FAC) was cement: water: sand: fine aggregate: coarse aggregate $=1: 0.48: 2.5: 3.2: 1.2$ by weight.

The mixture proportions of concrete specimens that were used are given in Table 1. Sand with fineness modulus of 2.40 and fine gravel $(4-8 \mathrm{~mm}$ ) were used as fine aggregates. Gravel (8-above $16 \mathrm{~mm}$ ) was used as coarse aggregate, respectively. As mentioned, four (4) deformed low-carbon reinforcing steel bars with a diameter of $12 \mathrm{~mm}$ were embedded in the 4 corners of the specimens' cross-section. The steel bars were used in as-received condition without any modification of the surface and the chemical composition (wt\%) of steel was $0.21 \mathrm{C}, 0.39 \mathrm{Cu}, 38 \mathrm{Ceq}, 0.022 \mathrm{P}, 0.028 \mathrm{~S}$.

The concrete mix designs that were examined can be divided into two groups based on their compositions. The first group consists of the first 3 concrete compositions ( $\mathrm{CC} 1, \mathrm{CC} 2, \mathrm{CC} 3$ ) that are based on the $\mathrm{C} 30 / 37 \mathrm{mix}$ design and the second group (FAC, SCC) consists of the compositions with finer mix arrangements (absence of coarse aggregate, $D_{\max }<16 \mathrm{~mm}$ ), as well as lower w/c and higher cement content $\left(\mathrm{kg} / \mathrm{m}^{3}\right)$.

Table 1. Mixture proportions of concrete specimens.

\begin{tabular}{cccccc}
\hline Designation & $\begin{array}{c}\text { w/c } \\
\text { ratio }\end{array}$ & $\begin{array}{c}\text { Water } \\
\left(\mathrm{kg} / \mathrm{m}^{3}\right)\end{array}$ & $\begin{array}{c}\text { Cement } \\
\left(\mathrm{kg} / \mathrm{m}^{3}\right)\end{array}$ & $\begin{array}{c}\text { Fine aggregate } \\
\left(\mathrm{kg} / \mathrm{m}^{3}\right)\end{array}$ & $\begin{array}{c}\text { Coarse aggregate } \\
\left(\mathrm{kg} / \mathrm{m}^{3}\right)\end{array}$ \\
\hline CC1 & 0.5 & 165 & 330 & 975 & 930 \\
CC2 & 0.5 & 165 & 330 & 975 & 930 \\
CC3 & 0.5 & 165 & 330 & 975 & 930 \\
FAC & 0.48 & 190 & 400 & 1260 & 495 \\
SCC & 0.4 & 200 & 500 & 1050 & 570 \\
\hline
\end{tabular}



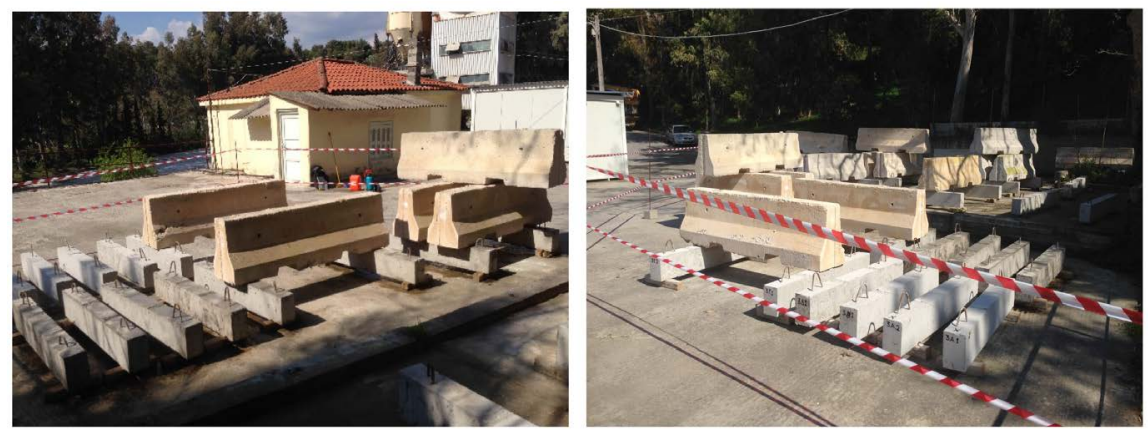

Figure 2. Beams and loading setup.

\subsection{Corrosion Test under Sustained Loading}

The chloride corrosion tests of the tested beams were conducted under simultaneous sustained flexural loading. The parameters for the corrosion tests included corrosion ratio and sustained loading level.

The specimens were tested regularly with electrochemical measurements for a total duration of 42 months. The tests included two steps: reference specimens and accelerated corrosion specimens. The reference specimens were carried out by exposing the beams to the environmental conditions. As expected, and shown from the test results, for the total period of 42 months corrosion did not initiate in any of the reference beams. To the rest of the beams, a wet/dry cycle of chloride solution was applied by surface spray. Electrochemical methods for corrosion assessment were conducted to measure the electrical properties of the electrically conductive bilayer (steel-solution interface) for the investigation of the corrosion mechanism and its monitoring and control. Half-cell potential tests were conducted following the ASTM C-867 guidelines, to determine the likelihood of active corrosion. A copper sulphate electrode (CSE) was used to assess the corrosion state of the reinforcement. Half-cell potential was measured at the end of each dry and wet stage [16]. Also, equipment that operates on the principle of the Wenner probe (Resimeter), was used to measure the surface electrical resistivity of the concrete. Surface resistivity measurement provides useful information about the state of a concrete structure. It has been proven to be linked to the likelihood of corrosion and the corresponding corrosion rate; recent studies have shown that there is a direct correlation between resistivity and chloride diffusion rate [17]. The values extracted from the tests were used in Equation (1) to get the $R$-value (Resistivity). Then, with the use of Ohm's Law, using the Voltage $(V)$ and resistivity $(R)$ values, the density of the corrosion current $I(\mathrm{~A})$ is extracted in each case.

$$
R(\Omega)=\frac{\rho}{2 \pi l} \times \ln \left(\frac{l^{2}}{t d}\right)
$$

The relationship between corrosion current density and the weight of metal lost due to corrosion, is determined using Faraday's Law, as follows:

$$
\Delta m=\frac{A I t}{Z F}
$$


where,

$$
\begin{aligned}
& \Delta m=\text { metal weight lost due to corrosion; } \\
& A=\text { atomic weight of iron (i.e. } 56 \mathrm{gr} \text { ); } \\
& I=\text { corrosion current (in amp); } \\
& t=\text { time elapsed (in sec); } \\
& Z=\text { valency of the reacting iron electrode (i.e. 2); } \\
& F=\text { Faraday's constant (i.e. } 96.500 \mathrm{amp} \times \mathrm{sec}) .
\end{aligned}
$$

The metal weight loss due to corrosion can also be expressed as:

$$
\Delta m=\delta \gamma \cdot \alpha \delta \gamma
$$

where,

$$
\begin{aligned}
& a=\text { reinforcing bar surface area before corrosion }\left(\mathrm{cm}^{2}\right) ; \\
& \delta=\text { material loss }(\mathrm{cm}) ; \\
& \gamma=\text { density of material }\left(\mathrm{g} / \mathrm{cm}^{3}\right) .
\end{aligned}
$$

The corrosion current can be expressed as:

$$
I=i \cdot a
$$

where,

$$
\begin{aligned}
& i=\text { corrosion current density }\left(\mathrm{amp} / \mathrm{cm}^{2}\right) . \\
& \text { Substituting from Equations (3) and (4) into (2) produces: }
\end{aligned}
$$

$$
\delta(\text { AIt } / \gamma \text { It })
$$

The above Equation (5) can be substituted considering steel reinforcement in concrete, the density of iron $\gamma=7.86 \mathrm{~g} / \mathrm{cm}^{3}$ and the values for $A, Z$, and $F$ (as calculated from the above equations).

If $R$ is defined as the material loss per year ( $\mathrm{cm} /$ year), its value can be determined from Equation (6) by substituting:

$t=1$ year (in appropriate units) to give:

$$
R=1156 i(\mathrm{~cm} / \text { year })
$$

As an example, for a corrosion current density $i$ of $1 \mathrm{~mA} / \mathrm{cm}^{2}$, the corrosion rate $R$ equals $1.156 \mathrm{~cm} /$ year [from Equation (6)].

If in a reinforced concrete structure, the period of corrosion after initiation is $T$ years, then the metal loss after $T$ years equals to $R T(\mathrm{~cm})$. Therefore, the percent reduction in the reinforcing bar diameter in $T$ years, can be calculated as follows:

$$
\% \text { reduction in bar diameter }=(2 R T / D R) \times 100
$$

The expression $2 R T / D$ percent, which represents reduction in reinforcing bar diameter due to corrosion over $T$ years, is also defined as the degree of reinforcement corrosion under study. Substituting for $R$ from Equation (6) into (7) produces:

$$
\% \text { reduction in bar diameter }=(2312 i T) / D
$$

In our study case, the total exposure time is 3.5 years. However, the interval set as $T$ in Formula (8) is 2 (years) since, as shown by electrochemical measure- 
ments, the initiation of corrosion occurred approximately 1.5 years after the beginning of the experiment. Taking this into consideration, as also observed in the calculations presented in this study's results, the period under consideration for study of the beams' calculated mass loss is from the 18th month until the 24th month (last test).

\section{Experimental Results and Discussion}

The concrete mix designs that were examined can be divided into two groups based on their compositions. The code names of the specimens were given as follows. The first group consists of the first 3 concrete compositions (CC1, CC2, CC3) that are based on the C30/37 mix design and the second group (FAC, SCC) consists of the compositions with finer mix arrangements (absence of coarse aggregate, Dmax $<16 \mathrm{~mm}$ ), as well as lower W/C and higher cement content $\left(\mathrm{kg} / \mathrm{m}^{3}\right)$. Regarding the loading ratio: 1) is for non-corroded beams (reference specimens), 2) is for (unloaded) artificial climate exposed specimens and 3) for artificial climate exposed specimens with a load that reaches $20 \%$ of the beam's yielding point.

\subsection{Half-Cell Potential Measurements}

Half-cell potential measurements are the most widely used method of detection of corrosion of steel reinforcement in concrete. The measurement of the corrosion potential of the steel using a reference electrode provides information on the corrosion rate (probability) embedder in cementitious materials. The Half-cell potential (Ecorr) is a thermodynamical dimension and shows only the tendency of steel rebar for corrosion but does not give information for the corrosion rate of reinforcement. Corrosion rate of reinforcements is affected by several factors, which can be the diffusion of oxygen, the concrete's porosity and the presence of highly resistive layer. Half-cell potential tests were conducted following the ASTM C-867 guidelines, to determine the likelihood of active corrosion with the use of a high-impedance voltammeter, between the tested beams and copper sulphate (CSE) as a reference electrode. Table 2 shows the corrosion condition for the steel's corrosion potential according to ASTM C-867 criteria with a CSE as a reference electrode.

Figure 3 presents the average period in months before limit potential value was observed in each case according to Table $2(-200,-350 \mathrm{mV})$. Half-cell

Table 2. Corrosion potential and corrosion condition with copper sulphate (CSE) as a reference electrode.

\begin{tabular}{cc}
\hline Copper/Copper sulphate & Corrosion condition \\
\hline$>-200 \mathrm{mV}$ & Low (10\% risk of corrosion) \\
-200 to $-350 \mathrm{mV}$ & Intermediate corrosion risk \\
$<-350 \mathrm{mV}$ & High $(>90 \%$ risk of corrosion) \\
$<-500 \mathrm{mV}$ & Severe corrosion \\
\hline
\end{tabular}




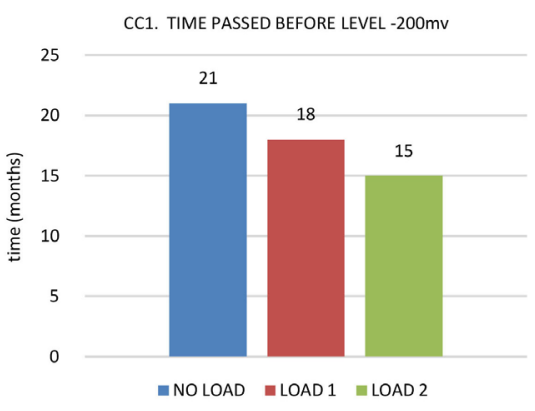

(a)

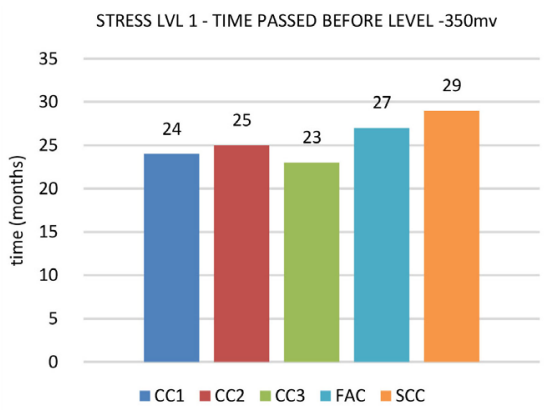

(b)

Figure 3. Period before corrosion initiation according to ASTM C-867: (a) each loading case for $\mathrm{CC} 1$; (b) compositions comparison.

potential was measured at the time that specimens were exposed to the corrosive environment ("zero" time) for a total period of 42 months.

According to ASTM C876-09, when the measured corrosion potential is lower than $350 \mathrm{mV}$ vs CSE, a greater than $90 \%$ possibility of reinforcement corrosion occurs and when the measured corrosion potential is $-200 \mathrm{mV}$, an intermediate chance of corrosion occurs.

As shown above, corrosion initiation (potential values below $-200 \mathrm{mV}$ ) took 15 to 18 months for sustained loading beams and 21 months for unloaded beams showing that sustained loading had an impact in corrosion initiation. Also, limit corrosion values (potential $<-350 \mathrm{mV}$ ) took 23 to 25 months for C30/37 based mix designs (CC1, CC2, CC3) and 27 to 29 months for the finer mix designs (FAC, SCC) showing that lower $\mathrm{w} / \mathrm{c}$ ratio as well as more cement content $\left(\mathrm{kg} / \mathrm{m}^{3}\right)$ in a composition improves its anticorrosion behavior [18] [19]. Figure 4 below shows the monitored corrosion potential of the tested RC beams for a total period of 42 months. It can be seen that the potentials of all test groups for the first 18 measurements are between $-140 \mathrm{mV}$ and $-440 \mathrm{mV}$. The potential of the unloaded test group ranged between $-100 \mathrm{mV}$ and $-350 \mathrm{mV}$, from the $1 \mathrm{st}$ load ratio ranged between $-140 \mathrm{mV}$ and $-440 \mathrm{mV}$ and from the 2nd load ratio ranged between $-180 \mathrm{mV}$ and $-430 \mathrm{mV}$.

The specimens in which corrosion inhibitor has been added as an additive (CC2) exhibit more positive values than the other beams in the same group (CC1, CC3). It is observed that the corrosion inhibitor that was used as an additive is activated after a short period of time. A reason for that is likely to be that the additive corrosion inhibitor molecules are in a crystalline structure; thus, released after six months. On the other hand, the specimens with organic coating on their surface exhibit more electropositive values but not as high as the specimens with the additive corrosion inhibitor [20]. Also, as expected, the reference specimens (not exposed to $\mathrm{NaCl}$ solution) appear to exhibit more electropositive values than the other groups showing that corrosion may not have happened at the steel bars. Respectively the mixtures with finest aggregates (FAC, SCC) had shown the most electropositive values, showing again that lower w/c ratio, as well as more cement $\left(\mathrm{kg} / \mathrm{m}^{3}\right)$ in a concrete composition, improve its anticorrosion 


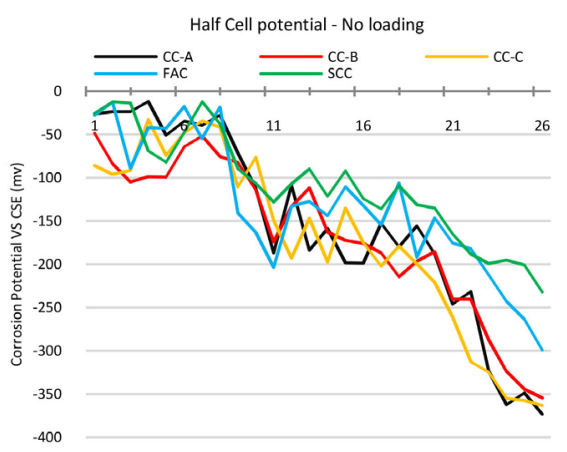

(a)

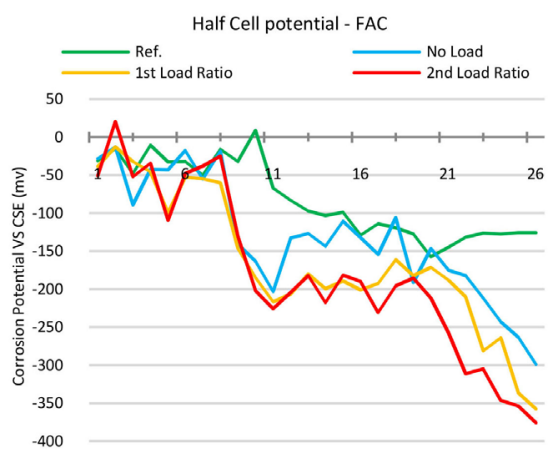

(b)

Figure 4. Half Cell potential of tested beams versus time (a) unloaded beams: (b) loaded beams.

behaviour more than when corrosion inhibitors or surface sealants are used. Moreover, sustained loading accelerated the corrosion initiation. The tensile stress applied to reinforcement may weaken the passivated film, resulting in early failure of this protective film under chloride attack [21]. A similar phenomenon was reported by Berrocal et al., where corrosion initiation was faster in sustained load beams. Sustained loading levels may affect the corrosion potential of beams. As shown in Figure 4, the corrosion potential reached $300 \mathrm{mV}$ for beam CCA-1 (no load) to $380 \mathrm{mV}$ for beam CCA-3 (2nd load ratio) with increasing sustained loading and this phenomenon was observed in almost all mix design cases and it was consistent with the results reported by Berrocal et al., where the corrosion potential of non-loaded beams was lower than that of sustained load beams.

\subsection{Corrosion Electrical Resistance}

Corrosion electrical resistance can serve as a macro-parameter to represent the effect of corrosion products and cracks on corrosion development. Equipment that operates on the principle of the Wenner probe (Resimeter), was used to measure the surface electrical resistivity of the concrete. Figure 5 shows the electrical resistance throughout the corrosion process for selected beams: the initial electrical resistance was similar for all tested beams and only the beams under no sustained loads had larger electrical resistance values.

As observed, the electrical resistance increased with corrosion age for the first period of $8-10$ months, especially for SCC specimens. Then, it decreased with corrosion development, for all concrete specimens. As shown in Figure 5 the specimens reached their top resistance values almost simultaneously after 8 - 10 months of testing. Values at this period ranged between $400 \Omega$ and $500 \Omega$. Although then a decrease was observed, mainly as a result of corrosion initiation and electrical resistance, values ranged between $140 \Omega$ and $440 \Omega$. This behaviour was consistent with the results reported by Berrocal et al. which showed that electrical resistance increased before corrosion cracking and then decreased with corrosion development, for reinforced concrete specimens [22] [23]. 


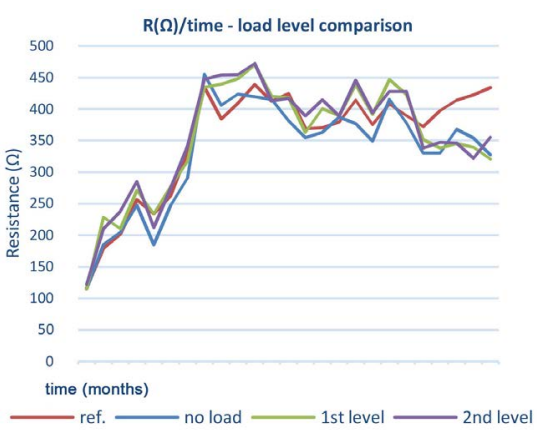

(a)

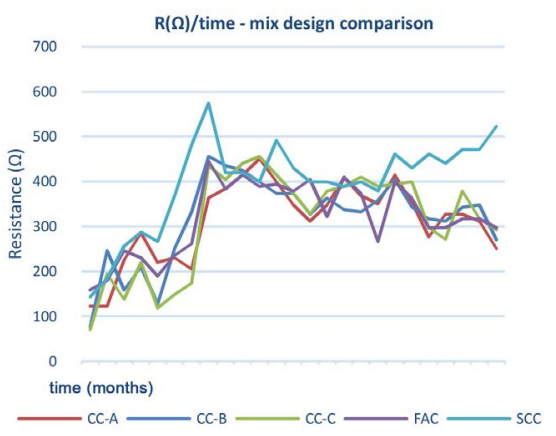

(b)

Figure 5. Corrosion electrical resistance with corrosion age for selected beams: (a) for tested compositions; (b) for tested loading levels.

\subsection{Determination of the Corrosion Ratio}

The actual average corrosion rate can be determined via the method expressed in Equation $(8)$ where: $\%$ reduction in bar diameter $=(2312 i T) / D$. That represents reduction in reinforcing bar diameter due to corrosion over $T$ years where, $i=$ corrosion current density $\left(\mathrm{amp} / \mathrm{cm}^{2}\right)$ and $D$ is the reinforcing bar diameter. In our study case, the total exposure time is 3.5 years. However, the interval set as $T$ in Formula (8) is 2 years since, as shown by electrochemical measurements, the initiation of corrosion occurred approximately 1.5 years after the tests began. That considered, as demonstrated by the results, the period considered for calculating the mass loss is from the 18th until the 42nd month (last test). The calculated average corrosion rates for each case are summarized in Table 3.

In order to make some comparable conclusions for the corrosion condition for every group of specimens, the measurements of the mass loss (gr) are presented graphically versus time. Figure 6 is presented the calculated electrochemical mass loss of the steel rebar of specimens versus time for each loading case. Generally, from Figure 6 as expected, the electrochemical mass loss increases with time for all groups. The electrochemical mass loss of the specimens with corrosion inhibitors (CC2, CC3) is smaller but at the same level with the mass loss of the reference specimens without protection (CC1) [24] [25]. That shows that the protection that was used with corrosion inhibitor or with surface sealant was not as effective as expected. From Figure 6, it is evident that SCC had the smaller mass loss by far, proving that self-compacting concrete is a durable concrete mix design because of the low w/c ratio (0.4) as well as the high cement content $\left(500 \mathrm{~kg} / \mathrm{m}^{3}\right)$.

Among specimens that a corrosion inhibitor was used, specimens containing $4 \% \mathrm{w} / \mathrm{t}$ corrosion inhibitor exhibits smaller mass loss than the specimens sprayed on their surface. Comparing the two groups in which an organic coating was used, it is observed that after the final measurement, specimens in which the organic coating was applied on the external surface exhibit 15\% more mass loss that beams where corrosion inhibitor was used. This difference may be due to the failure of the applied coating [26] [27]. A failure at the film could result in a 


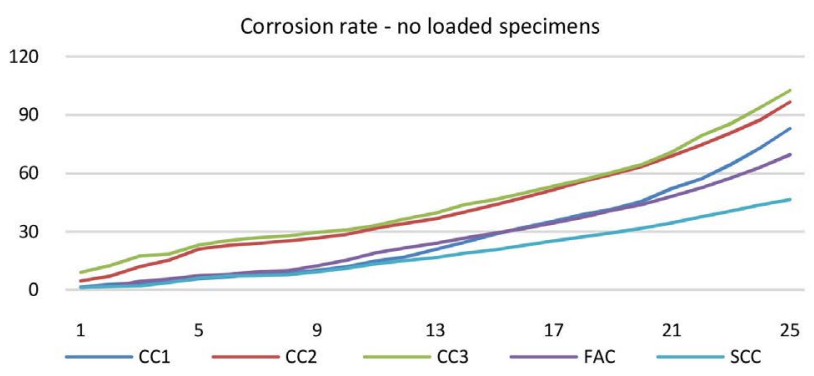

(a)

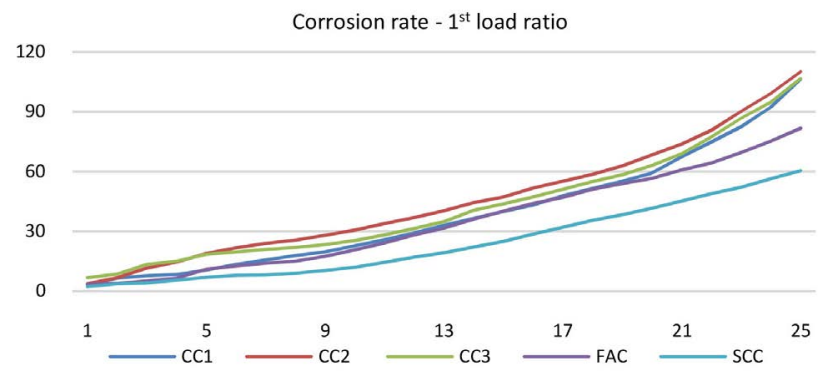

(b)

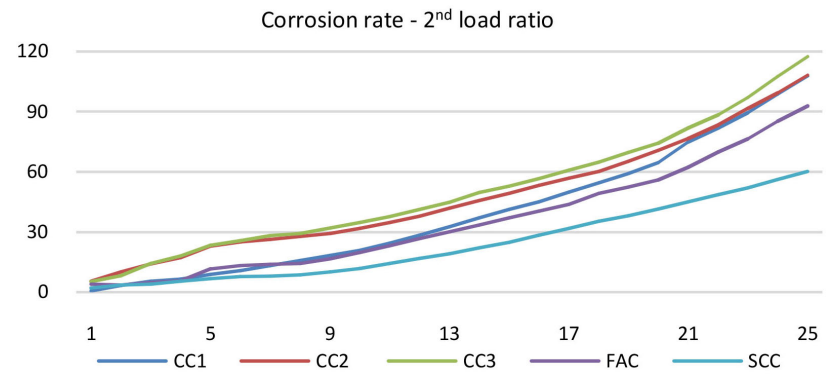

(c)

Figure 6. Electrochemical mass loss versus time for unloaded, $7 \%$ stress ratio and $20 \%$ stress ratio.

Table 3. Corrosion rates (m\%/year) of tested beams with different sustained loading levels.

\begin{tabular}{cccc}
\hline Designation & $\begin{array}{c}\text { Corr. rate } \\
\text { No stress }\end{array}$ & $\begin{array}{c}\text { Corr. rate } \\
\text { Lvl 1 stress }\end{array}$ & $\begin{array}{c}\text { Corr. rate } \\
\text { Lvl 2 stress }\end{array}$ \\
\hline CC1 & 2.76 & 3.26 & 3.38 \\
CC2 & 2.65 & 3.09 & 2.97 \\
CC3 & 2.79 & 3.16 & 3.23 \\
FAC & 2.11 & 2.38 & 2.84 \\
SCC & 1.37 & 1.88 & - \\
\hline
\end{tabular}

total or partial film protection failure as the harmful substances of the environment will penetrate the beams and reach faster the reinforcement bars.

\section{Conclusions}

In this paper, the corrosion behavior of RC beams with different stress ratios and 
chlorides attack was investigated, and then the flexural performance after corrosion was tested. The following conclusions can be drawn:

1) An inversely proportional relationship of the water/cement ratio of a composition with its corrosion behavior was observed. Smaller w/c values (0.4 instead of 0.5 ) lead to better anti-corrosion resistance.

2) An analogous relationship between the cement content of a composition and its corrosion behavior was observed. In particular increase of cement (100 $\mathrm{kg} / \mathrm{m}^{3}$ ) leads to more electropositive values of corrosion potential and better anticorrosion behavior in general.

3) Corrosion electrical resistance in the accelerated corrosion stage increased with corrosion time for the first period, especially for SCC specimen and then it decreased with corrosion development, for all concrete specimens. This behaviour was consistent with other reported results which showed that electrical resistance increased before corrosion cracking and then decreased with corrosion development, for reinforced concrete specimens.

4) Corrosion inhibitors either as additives or in sprayed form show increase of the life expectancy of a structure but not to a great extent. Specifically, the specimens with corrosion inhibitors showed improved anticorrosion behavior compared to the reference specimen. However, at both loading levels, their corrosion rate values tended to be similar to those of conventional concrete. This is probably due to the fact that the application of these materials partially failed with simultaneous load application.

5) The corrosion rate of steel is increased gradually with increasing load. A small level of sustained load (7\%) has little effect on rate of corrosion. Although a bigger level of sustained load (20\%) has a clear effect on rate of corrosion.

6) Mix designs that improve corrosion resistance are not substantially different from the proportions of good quality concrete. Low w/c ratios, as well as increased cement content $\left(\mathrm{kg} / \mathrm{m}^{3}\right)$ in concrete composition leads to better anticorrosion resistance without the need to use other protection methods (inhibitors, coatings, etc.).

\section{Acknowledgements}

The authors wish to sincerely thank KOUROS Concrete Company and especially Mr. Elias Katsafados, Directing Manager, for his contribution to the main experimental part of the research.

\section{Conflicts of Interest}

The authors declare no potential conflicts of interest with respect to the research, authorship, and/or publication of this article.

\section{References}

[1] Martín-Pérez, Zibara, H., Hooton, R.D. and Thomas, M.D.A. (2000) Study of the Effect of Chloride Binding on Service Life Predictions. Cement and Concrete Research, 30, 1215-1223. https://doi.org/10.1016/S0008-8846(00)00339-2 
[2] Val, D.V. and Stewart, M.G. (2003) Life-Cycle Cost Analysis of Reinforced Concrete Structures in Marine Environments. Structural Safety, 25, 343-362. https://doi.org/10.1016/S0167-4730(03)00014-6

[3] Poupard, O., L'Hostis, V., Catinaud, S. and Petre-Lazar, I. (2006) Corrosion Damage Diagnosis of a Reinforced Concrete Beam after 40 Years Natural Exposure in Marine Environment. Cement and Concrete Research, 36, 504-520. https://doi.org/10.1016/j.cemconres.2005.11.004

[4] Berke, N.S. and Hicks, M.C. (1992) Estimating the Life Cycle of Reinforced Concrete Decks and Marine Piles Using Laboratory Diffusion and Corrosion Data. Symposium on Corrosion Forms and Control for Infrastructure, San Diego, 3-4 November 1991, 207-231.

[5] Ouglova, A., Berthaud, Y., Foct, F., François, M., Ragueneau, F. and Petre-Lazar, I. (2008) The Influence of Corrosion on Bond Properties between Concrete and Reinforcement in Concrete Structures. Materials and Structures, 41, 969-980. https://doi.org/10.1617/s11527-007-9298-x

[6] Tee, K.F. and Li, C.Q. (2011) A Numerical Study of Maintenance Strategy for Concrete Structures in Marine Environment. 11 th International Conference on Applications of Statistics and Probability in Civil Engineering, Zurich, 1-4 August 2011, 618-625. https://doi.org/10.1201/b11332-94

[7] Angst, U.M., Elsener, B., Larsen, C.K. and Vennesland, Ø. (2011) Chloride Induced Reinforcement Corrosion: Electrochemical Monitoring of Initiation Stage and Chloride Threshold Values. Corrosion Science, 53, 1451-1464. https://doi.org/10.1016/j.corsci.2011.01.025

[8] Montemor, M., Simoes, A. and Ferreira, M. (2003) Chloride-Induced Corrosion on Reinforcing Steel: From the Fundamentals to the Monitoring Techniques. Cement and Concrete Composites, 25, 491-502. https://doi.org/10.1016/S0958-9465(02)00089-6

[9] Cao, C., Cheung, M.M. and Chan, B.Y. (2013) Modelling of Interaction between Corrosion-Induced Concrete Cover Crack and Steel Corrosion Rate. Corrosion Science, 69, 97-109. https://doi.org/10.1016/j.corsci.2012.11.028

[10] Zhang, F., Pan, J.S. and Lin, C.J. (2009) Localized Corrosion Behaviour of Reinforcement Steel in Simulated Concrete Pore Solution. Corrosion Science, 51, 2130-2138. https://doi.org/10.1016/j.corsci.2009.05.044

[11] Alvarez, S., Bautista, A. and Velasco, F. (2011) Corrosion Behaviour of Corrugated Lean Duplex Stainless Steels in Simulated Concrete Pore Solutions. Corrosion Science, 53, 1748-1755. https://doi.org/10.1016/j.corsci.2011.01.050

[12] Shi, J.J., Sun, W., Jiang, J.Y. and Zhang, Y.M. (2016) Influence of Chloride Concentration and Pre-Passivation on the Pitting Corrosion Resistance of Low-Alloy Reinforcing Steel in Simulated Concrete Pore Solution. Construction and Building Materials, 111, 805-813. https://doi.org/10.1016/j.conbuildmat.2016.02.107

[13] Duffo, G., Morris, W., Raspini, I. and Saragovi, C. (2004) A Study of Steel Rebars Embedded in Concrete during 65 Years. Corrosion Science, 46, 2143-2157. https://doi.org/10.1016/j.corsci.2004.01.006

[14] Zhao, Y.X., Yu, J. and Jin, W.L. (2011) Damage Analysis and Cracking Model of Reinforced Concrete Structures with Rebar Corrosion. Corrosion Science, 53, 33883397. https://doi.org/10.1016/j.corsci.2011.06.018

[15] Wang, J.J., Basheer, P.A.M., Nanukuttan, S.V., Long, A.E. and Bai, Y. (2016) Influence of Service Loading and the Resulting Micro-Cracks on Chloride Resistance of Concrete. Construction and Building Materials, 108, 56-66. 
https://doi.org/10.1016/j.conbuildmat.2016.01.005

[16] Poursaee, A. and Hansson, C.M. (2008) The Influence of Longitudinal Cracks on the Corrosion Protection Afforded Reinforcing Steel in High Performance Concrete. Cement and Concrete Research, 8, 1098-1105. https://doi.org/10.1016/j.cemconres.2008.03.018

[17] Ababneh, A. and Sheban, M. (2011) Impact of Mechanical Loading on the Corrosion of Steel Reinforcement in Concrete Structures. Materials and Structures, 44, 1123-1137. https://doi.org/10.1617/s11527-010-9688-3

[18] Shi, J.J. and Sun, W. (2010) Evaluation of Steel Corrosion in Concrete under Simultaneous Flexural Load and Chloride Attacks. Journal of the Chinese Ceramic Society, 38, 1201-1208.

[19] Hariche, L., Ballim, Y., Bouhicha, M. and Kenai, S. (2012) Effects of Reinforcement Configuration and Sustained Load on the Behaviour of Reinforced Concrete Beams Affected by Reinforcing Steel Corrosion. Cement and Concrete Composites, 34, 1202-1209. https://doi.org/10.1016/j.cemconcomp.2012.07.010

[20] Li, C.Q. (2000) Corrosion Initiation of Reinforcing Steel in Concrete under Natural Salt Spray and Service Loading-Results and Analysis. ACI Materials Journal, 97, 690-697. https://doi.org/10.14359/9983

[21] Feng, X.G., Tang, Y.M. and Zuo, Y. (2011) Influence of Stress on Passive Behaviour of Steel Bars in Concrete Pore Solution. Corrosion Science, 53, 1304-1311. https://doi.org/10.1016/j.corsci.2010.12.030

[22] Feng, X.G., Zuo, Y., Tang, Y.M., Zhao, X.H. and Lu, X.Y. (2011) The Degradation of Passive Film on Carbon Steel in Concrete Pore Solution under Compressive and Tensile Stresses. Electrochimica Acta, 58, 258-263. https://doi.org/10.1016/j.electacta.2011.09.035

[23] Li, G.P., Hu, F.J. and Wu, Y.X. (2011) Chloride Ion Penetration in Stressed Concrete. Journal of Materials in Civil Engineering, 23, 1145-1153. https://doi.org/10.1061/(ASCE)MT.1943-5533.0000281

[24] Wang, H.L., Lu, C.H., Jin, W.L. and Bai, Y. (2011) Effect of External Loads on Chloride Transport in Concrete. Journal of Materials in Civil Engineering, 23, 1043-1049. https://doi.org/10.1061/(ASCE)MT.1943-5533.0000265

[25] Wang, Z.D., Yao, Y. and Wang, L. (2011) Corrosion Behavior of Steel Bar Embedded in Concrete Subject to Freeze-Thaw Cycles-Chloride Attack-Flexural Load. Journal of the Chinese Ceramic Society, 39, 1022-1027.

[26] Jaffer, S. and Hansson, C. (2008) The Influence of Cracks on Chloride-Induced Corrosion of Steel in Ordinary Portland Cement and High Performance Concretes Subjected to Different Loading Conditions. Corrosion Science, 50, 3343-3355. https://doi.org/10.1016/j.corsci.2008.09.018

[27] Jaffer, S.J. and Hansson, C.M. (2009) Chloride-Induced Corrosion Products of Steel in Cracked-Concrete Subjected to Different Loading Conditions. Cement and Concrete Research, 39, 116-125. https://doi.org/10.1016/j.cemconres.2008.11.001 